DOI: $10.31933 / \mathrm{JIMT}$

Received: 7 Agustus 2020, Revised: 25 Agustus 2020, Publish: 21 September 2020

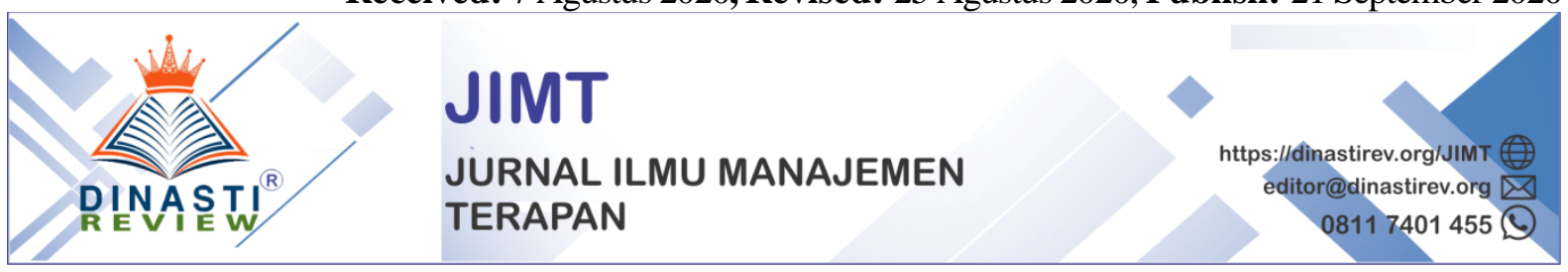

\title{
DETERMINAN KINERJA DENGAN MOTIVASI SEBAGAI MEDIASI PADA PT. TRI WANKA SEJAHTERA
}

\author{
Laynita Sari', Renil Septiano ${ }^{2}$ \\ ${ }^{1)}$ Program Doktoral UPI YPTK Padang, laynitasari4@gmail.com \\ ${ }^{2)}$ Program Doktoral UPI YPTK Padang, renil.septiano@ gmail.com
}

\section{Corresponding Author: First Author}

Abstrak: Kelangsungan dan kesuksesan suatu perusahaan sangat ditentukan oleh kualitas sumber daya manusia yang sesuai dengan sasaran kerja pegawai dan prilaku kerja, khususnya kinerja. Apabila kinerja karyawan meningkat, maka produktivitas perusahaan juga akan meningkat. Sumber daya manusia merupakan faktor penting dalam keberlangsungan perusahaan. Oleh karena itu perusahaan harus mengetahui faktor apa saja yang akan mendukung atau menghambat dalam mencapai tujuan perusahaan. Tujuan dari penelitian ini untuk mengetahui bagaimana pengaruh kompetensi, beban kerja, motivasi terhadap kinerja karyawan PT. Tri Wanka Sejahtera. Hasil dari penelitian ini bahwa kompetensi secara tidak langsung berpengaruh terhadap kinerja yang dimediasi oleh motivasi, dan beban kerja tidak berpengaruh secara tidak langsung yang dimediasi oleh motivasi.

Kata Kunci: Kinerja, Motivasi, Mediasi

\section{PENDAHULUAN}

PT. Tri Wanka Sejahtera merupakan PT yang bergerak di dunia pariwisata mulai dari perencanaan wisata hingga pengelolaan lini bisnis Pariwisata. PT. Tri Wanka Sejahtera bergerak di bidang tiketing untuk penjualan tiket pesawat hingga penjualan paket-paket wisata dalam negri dan luar negri. Dari tahun 2017-2019 persaingan di dunia travel sangat ketat, oleh karena itu SDM dari setiap bagian sangatlah berperan penting untuk memenangkan persaingan ini.

Tingginya beban kerja dapat mempengaruhi penurunan kualitas karyawan. Menurut Haryanto (2004) beban kerja adalah dimana dalam waktu tertentu dan kedaan normal seseorang ataupun sekelompok orang harus menyelesaikan sejumlah kegiatan. Apabila beban kerjanya meningkat, maka kualitas kerja karyawan pun akan rendah dalam menyelesaikan pekerjaannya. Apabila kemampuan dari karyawan lebih tinggi dari beban kerjanya, maka karyawan akan merasa bosan. Apabila beban kerja yang diberikan kepd karyawan lebih banyak dibandingkan kemampuannya, maka pekerjaan tidk akan selesi tepat waktu. 
Menurut Thoha (2008), manusia adalah faktor utama dalam setiap organisasi yang memiliki karakteristik seperti kemampuan, kepercayaan pribadi, pengharapan, kebutuhan, dan pengalaman. Komponen karakteristik inilah yang kemudian membentuk perilaku pegawai. Selanjutya, organisasi merupakan suatu wadah untuk mencapai tujuan dan manusialah yang akan membawa organisasi tersebut untuk mencapai tujuan. Sehubungan dengan hal tersebut, diperlukan kompetensi dalam bekerja untuk mencapai tujuan perusahaan.

Dengan adanya kompetensi sumber daya manusia maka waktu pemprosesan tiket, pelayanan kepada nasabah dapat efisien, karena sumber daya manusia tersebut telah memiliki pengetahuan dan pemahaman mengenai hal-hal yang dikerjakan sehingga pekerjaannya dapat diselesaikan dan disajikan tepat pada waktunya. Karyawan yang memiliki kompetensi dapat dilihat dari perilakunya seperti disiplin dalam bekerja, taat pada peraturan yang berlaku, bertanggungjawab dalam pekerjaannya dan sebagainya. Tingginya beban kerja pada karyawan dapat mempengaruhi perilakunya seperti kurang konsentrasi, kelelahan dan jenuh dalam bekerja akibatnya pekerjaan tidak terselesaikan pada jadwal yang telah ditentukan.

Penelitian sebelumnya mengenai beban kerja yaitu pada penelitian beban kerja profesi auditor pada penelitian Fahriani (2015) dalam penelitiannya pada KAP Big Four menyatakan bahwa beban kerja tidak berpengaruh signifikan terhadap kualitas audit pada Kantor Akuntan Publik Big Four. Hasil yang berbeda ditunjukkan oleh Fitriany dan Setiawan (2011) yang hasilnya menunjukkan beban kerja terbukti berpengaruh negatif terhadap kualitas audit.

Fenomena yang terjadi pada PT. Tri Wanka Sejahtera yang saya temui adalah belum maksimalnya pencapaian hasil dengan target yang teaj ditentukan, masih adanya karyawan yang tidak kompeten di bidang kerjanya, dan masih adanya karyawab yang memiliki beban kerja ganda di perusahaan.

Tujuan dari penelitian ini adalah untuk menganalisis pengaruh kompetensi terhadap motivasi karyawan PT. Tri Wanka Sejahtera, menganalisis pengaruh beban kerja terhadap motivasi Karyawan PT. Tri Wanka Sejahtera, menganalisis pengaruh kompetensi terhadap kinerja PT. Tri Wanka Sejahtera, mengnalisis pengaruh beban kerja terhadap kinerja PT. Tri Wanka Sejahtera, menganalisis pengaruh kompetensi terhadap kinerja yang dimediasi oleh motivasi karyawan PT. Tri Wanka Sejahtera, dan menganalisis pengaruh beban kerja terhadap kinerja yang di mediasi oleh motivasi karyawan PT. Tri Wanka Sejahtera.

\section{KAJIAN PUSTAKA}

Kompetensi merupakan karakter yang mendasar pada setiap individu meliputi pengetahuan, keterampilan serta sikap kerja sehingga membuat orang tersebut menjadi unggul 
dalam bekerja.Dengan kompetensi baik yang dimiliki oleh seorang pegawai maka pegawai tersebut akan memiliki motivasi kerja yang baik juga pada instansi tempat ia bekerja. Sehingga hal ini akan meningkatkan motivasi dalam diri pegawai terhadap instansi tempat ia bekerja. Priansa (2016) berpendapat bahwa: "Kompetensi adalah kapasitas yang dimiliki pegawai, yang mengarah kepada perilaku yang sesuai dengan tuntutan pekerjaan serta sesuai dengan ketetapan organisasi, yang pada gilirannya akan membawa hasil seperti yang diinginkan.

Hasil kajian teoritis dan pendapat ahli tentang kompetensi dan motivasi diperkuat oleh hasil penelitian terdahulu dari Gunawan, (2015) Kompetensi berpengaruh positif secara langsung dan signifikan terhadap Motivasi pegawai UPTD Pendapatan Wilayah I Palu. Dan hasil penelitian Dandy Rahman, dkk, (2014) bahwa Kompetensi berpengaruh signifikan terhadap Motivasi (Studi Kasus Pada Karyawan Bagian Pabrik PT. Jember Indonesia.

Berdasarkan kajian teoritis, pendapat ahli dan hasil penelitian terdahulu diatas dapat dilihat bahwa adanya pengaruh signifikan dari kompetensi terhadap motivasi. Hal ini berarti bahwa diasumsikan ada hubungan dan pengaruh positif/signifikan antara kompetensi dengan motivasi, sehingga ini berarti apabila kompetensi yang baik maka akan meningkatkan motivasi karyawan PT. Tri Wanka Sejahtera. Maka dapat peneliti turunkan hipotesis pertama sebagai berikut :

H1 : Kompetensi memberikan pengaruh signifikan terhadap motivasi karyawan PT. Tri Wanka Sejahtera

Beban kerja adalah sekumpulan atau sejumlah kegiatan yang harus diselesaikan oleh suatu unit organisasi atau pemegang jabatan dalam jangka waktu tertentu. Berdasarkan teori, beban kerja mempengaruhi bukan hanya kondisi fisik karyawan tetapi juga kondisi psikis. Dalam hal ini kondisi psikis yang dimaksud adalah faktor motivasi kerja. Oleh karena itu, beban kerja akan mempengaruhi motivasi kerja karyawan mereka. Beban kerja menurut Suwatno (2003) merupakan sejumlah kegiatan yang harus diselesaikan oleh suatu unit organisasi atau pemegang jabatan secara sistematis dengan menggunakan teknik analisis jabatan, teknik analisa beban kerja atau teknik manajemen lainnya dalam jangka waktu tertentu untuk mendapatkan informasi tentang efisiensi dan efektifitas kerja suatu unit organisasi. Beban kerja setiap pegawai berbeda - beda tergantung fungsi dimana pegawai tersebut berada.

Hasil analisis Gozali (2016) menunjukkan bahwa beban kerja berpengaruh negatif dan signifikan terhadap kinerja karyawan. Semakin tinggi beban kerja semakin rendah kinerja yang dihasilkan, demikian juga sebaliknya semakin rendah beban kerja maka kinerja pegawai semakin tinggi. Penelitian Muhammad (2016) menyimpulkan beban kerja berpengaruh 
signifikan terhadap kinerja karyawan. Berdasarkan uraian tersebut dapat dirumuskan hipotesis berikut:

\section{H2 : Beban kerja memberikan pengaruh signifikan terhadap motivasi karyawan PT. Tri Wanka Sejahtera.}

Kompetensi merupakan ciri seseorang yang dapat dilihat dari keterampilan, pengetahuan dan kemampuan yang dimilikinya dalam hal menyelesaikan tugas-tugas yang dibebankan kepadanya. Kompetensi dasar seseorang diperlukan untuk mencapai kinerja tinggi dalam menyelesaikan kinerjanya. Sehingga makin tinggi kompetensi seseorang makin meningkat pula kinerjanya. Menurut Spencer \& Spencer (2006) (dalam Manopo 2011:30) adalah sejumlah karakteristik individu yang berhubungan dengan acuan kriteria perilaku yang diharapkan dan kinerja terbaik dalam sebuah pekerjaan atau situasi yang diharapkan untuk dipenuhi.

Umar Makawi, dkk, (2015) dalam penelitiannya bahwa Kompetensi berpengaruh signifikan terhadap Kinerja Pegawai Dinas Perindustrian. Hal ini berarti bahwa diasumsikan ada hubungan dan pengaruh positif/signifikan antara kompetensi dengan kinerja, sehingga ini berarti apabila kompetensi yang baik maka akan meningkatkan kinerja karyawan PT. Tri Wanka Sejaahtera. Maka dapat peneliti turunkan hipotesis keempat sebagai berikut :

\section{H3 : Kompetensi memberikan pengaruh signifikan terhadap kinerja karyawan PT. Tri Wanka Sejahtera}

Beban kerja menurut Meshkati dalam Hariyati (2011) dapat didefinisikan sebagai suatu perbedaan antara kapasitas atau kemampuan pekerja dengan tuntutan pekerjaan yang harus dihadapi. Permendagri No. 12/2008 menyatakan bahwa beban kerja adalah besaran pekerjaan yang harus dipikul oleh suatu jabatan/unit organisasi dan merupakan hasil kali antara volume kerja dan norma waktu.

Penelitian yang dilakukan Iskandar (2012) tentang pengaruh beban kerja, motivasi kerja dan kepuasan kerja terhadap kinerja pegawai Bank BJB Padalarang”. Hasil penelitian ini mengatakan bahwa penelitian menyimpulkan bahwa pengaruh Beban Kerja sangat besar terhadap motivasi dan kepuasan kerja pegawai, yang pada akhirnya akan mempengaruhi pula kinerja dalam pelaksanaan pekerjaan. Artinya beban kerja memberikan pengaruh yang signifikan terhadap kinerja, beban kerja yang dirasakan dapat menentukan perilaku kerja atau kinerja pegawai bank bjb cabang Padalarang.

Hal ini berarti bahwa diasumsikan ada hubungan dan pengaruh positif/signifikan antara beban kerja dengan kinerja, sehingga ini berarti apabila beban kerja yang baik maka akan 
meningkatkan kinerja karyawan PT. Tri Wanka Sejahtera. Maka dapat peneliti turunkan hipotesis kelima sebagai berikut :

\section{H4 : Beban Kerja memberikan pengaruh signifikan terhadap kinerja karyawan PT. Tri Wanka Sejahtera}

Robbins dan Jugde (2008) mendefinisikan motivasi sebagai proses yang menjelaskan intensitas, arah dan ketekunan seorang individu untuk mencapai tujuannya. Robbins (2008) dalam pandangan yang lain mengemukakan bahwa pengertian motivasi kerja meliputi upaya (effort), tujuan organisasi (organizational goals), dan kebutuhan (needs). Unsur "upaya" merupakan intensitas. Upaya yang diarahkan tersebut haruslah konsisten dengan tujuan organisasi, adapun kebutuhan adalah keadaan internal yang menyebabkan hasil - hasil tertentu tampak menarik. Penelitian yang dilakukan oleh Taroreh (2014) menunjukkan hasil bahwa motivasi kerja berpengaruh signifikan positif terhadap kinerja. Penelitian yang dilakukan oleh Waisnawini (2014) menyimpulkan bahwa motivasi kerja berpengaruh positif dan signifikan terhadap kinerja karyawan. Berdasarkan uraian tersebut dapat dirumuskan hipotesis berikut:

\section{H5 : Motivasi kerja berpengaruh signifikan terhadap kinerja karyawan PT. Tri Wanka Sejahtera}

Robbins (2008:17) menyatakan motivasi merupakan proses yang berperan pada intensitas, arah, dan lamanya berlangsung upaya individu ke arah pencapaian sasaran. Motivasi dapat didefinisikan sebagai keadaan dimana usaha dan kemauan keras seseorang diarahkan kepada pencapaian hasil tertentu (Nimran, 2009). Motivasi dapat dipastikan mempengaruhi kinerja, walaupun bukan satu-satunya faktor yang membentuk kinerja (Wibowo, 2007). Hal ini didukung oleh hasil penelitian yang telah dilakukan oleh Larasati dan Gilang (2014). Motivasi sangat diperlukan, setiap individu memerlukannya sebagai pendorong agar dapat lebih semangat dalam melaksanakan pekerjaannya. Motivasi seseorang untuk bekerja biasanya melibatkan faktor-faktor individual dan organisasi. Maka dapat peneliti turunkan hipotesis keenam dan ketujuh sebagai berikut :

H6 : Motivasi memberikan pengaruh yang positif dan signifikan sebagai mediasi antara kompetensi terhadap kinerja karyawan PT. Tri Wanka Sejahtera

H7 : Motivasi memberikan pengaruh yang positif dan signifikan sebagai mediasi antara beban kerja terhadap kinerja kayawan PT. Tri Wanka Sejahtera 


\section{METODE PENELITIAN}

Jenis penelitian adalah analisa kuantitatif, metode analisis data yang digunakan dalam penelitian ini adalah analisis jalur (path analysis). Analisis jalur merupakan perluasan dari analisis regresi linier berganda, atau analisis jalur adalah penggunaan analisis regresi untuk menaksir hubungan kausalitas antara variabel (Model Kausal) yang telah ditetapkan sebelumnya. Obyek penelitian ini adalah karyawan dari PT. Tri Wanka Sejahtera. Jenis data dalam penelitian ini adalah data primer yaitu data penelitian yang diperoleh atau dikumpulkan langsung dari sumber asli (tanpa perantara). Sumber data primer dalam penelitian ini diperoleh dari jawaban atas kuesioner yang dibagikan kepada responden. Selain itu data penelitian juga didapat dari literatur penelitian sebelumnya, juga dari buku, internet yang berkaitan dengan maslah penelitian.

Populasi dalam penelitian ini adalah seluruh karyawan dari PT. Tri Wanka Sejaahtera, sampel dalam penelitian ini adalah sama dengan populasi yaitu seluruh karyawan PT. Tri Wanka Sejahtera yang berjumlah 35 (tiga puluh lima) orang. Untuk sampel penelitian, digunakan seluruh populasi yang ada, karena jumlah populasi kurang dari 100 (seratus), Sugiyono (2017).

Teknik pengumpulan data pada penelitian ini adalah menggunakan kuesioner. Setelah data diperoleh hasilnya akan dipaparkan secara deskriptif dan seterusnya dianalisis untuk keperluan pengujian hipotesis yang telah dikembangkan (Bungin, 2010). Kuisioner dipakai untuk mendapatkan data primer yang disebarkan langsung kepada sampel terpilih dengan cara mendatangi responden. Dalam kuesioner tersebut berisikan pertanyaan tentang demografi responden seperti jenis kelamin, usia, pekerjaan, dan lamanya bekerja pad PT. Tri Wanka Sejahtera. Di samping itu, kuesioner juga memuat pernyataan tentang persepsi responden yang berkaitan dengan kompetensi, beban kerja, motivasi dan kinerja.

\section{HASIL DAN PEMBAHASAN}

Hasil uji hipotesis model 1 pengaruh kompetensi, beban kerja, terhadap motivasi dapat dilihat pada tabel 1 di bawah ini :

Tabel 1 Pengaruh Kompetensi, Beban Kerja Terhadap Motivasi

\begin{tabular}{|c|c|c|c|c|c|c|}
\hline \multirow[t]{2}{*}{ Model } & & \multicolumn{3}{|c|}{ Unstandardized Coef $\mid$ Standardized Coefficients } & \multirow[t]{2}{*}{$\mathbf{t}$} & \multirow[t]{2}{*}{ Sig. } \\
\hline & & B & Std. Error & Beta & & \\
\hline \multirow[t]{3}{*}{1} & (Constant) & 27.686 & 8.622 & & 3.211 & .003 \\
\hline & KOMPETENSI & .375 & .163 & .378 & 2.307 & .028 \\
\hline & BEBAN KERJA & -.006 & .125 & -.008 & -.047 & .962 \\
\hline
\end{tabular}

a. Dependent Variable: MOTIVASI

Dari hasil uji SPSS diatas dapat dirumuskan persamaan regresi sebagai berikut: 
Motivasi $=27,686+0,375$ Kompetensi $-0,006$ Beban Kerja

Hasil uji hipotesis model 2 pengaruh kompetensi, beban kerja, motivasi, terhadap kinerja dapat dilihat pada tabel 2 di bawah ini :

Tabel 2 Pengaruh Kompetensi, Beban Kerja, Motivasi Terhadap Kinerja

\begin{tabular}{ccccccc}
\hline \multirow{2}{*}{ Model } & \multicolumn{2}{c}{ Unstandardized Coefficients } & Standardized Coefficients & t & Sig. \\
& & B & Std. Error & Beta & & \\
\hline 1 & (Constant) & -2.062 & 9.095 & & -.227 & .822 \\
& KOMPETENSI & .350 & .161 & .314 & 2.169 & .038 \\
& BEBAN KERJA & .256 & .115 & .299 & 2.229 & .033 \\
& MOTIVASI & .436 & .162 & .389 & 2.691 & .011 \\
\hline
\end{tabular}

a. Dependent Variable: KINERJA

Dari hasil uji SPSS diatas dapat dirumuskan persamaan regresi sebagai berikut:

Kinerja $=-2,062+0,350$ Kompetensi + 0,256 Beban Kerja + 0,436 Motivasi

Hasil pengujian masing-masing varibel independen terhadap variabel dependennya dapat dianalisis sebagai berikut:

\section{Variabel kompetensi terhadap variabel motivasi}

H1 : Kompetensi memberikan pengaruh signifikan terhadap motivasi karyawan PT. Tri Wanka Sejahtera

Hasil pengujian pengaruh kompetensi terhadap motivasi diperoleh nilai t signifikansi sebesar 0,028. Nilai signifikansi lebih kecil dari 0,05 menunjukan bahwa kompetensi berpengaruh signifikan terhadap motivasi. Hal ini berarti Hipotesis 1diterima.

\section{Variabel beban kerja terhadap variabel motivasi}

H2 : Beban kerja memberikan pengaruh signifikan terhadap motivasi karyawan PT. Tri Wanka Sejahtera.

Hasil pengujian pengaruh beban kerja terhadap motivasi diperoleh nilai t signifikansi sebesar 0,962. Nilai signifikansi lebih besar dari 0,05 menunjukan bahwa beban kerja tidak berpengaruh signifikan terhadap motivasi. Hal ini berarti Hipotesis 2 ditolak.

\section{Variabel kompetensi terhadap variabel kinerja}

H3 : Kompetensi memberikan pengaruh signifikan terhadap kinerja karyawan PT. Tri Wanka Sejahtera 
Hasil pengujian pengaruh kompetensi terhadap kinerja diperoleh nilai t signifikansi sebesar 0,038. Nilai signifikannya kecil dari 0,05 berarti bahwa kompetensi berpengaruh secara signifikan terhadap kinerja. Hal ini berarti Hipotesis 3 diterima.

\section{Variabel beban kerja terhadap variabel kinerja}

H4 : Beban Kerja memberikan pengaruh signifikan terhadap kinerja karyawan PT. Tri Wanka Sejahtera

Hasil pengujian pengaruh kompetensi terhadap kinerja diperoleh nilai t signifikansi sebesar 0,033. Nilai signifikansi lebih kecil dari 0,05 menunjukan bahwa beban kerja berpengaruh signifikan terhadap kinerja. Hal ini berarti Hipotesis 4 diterima.

\section{Variabel motivasi terhadap variabel kinerja}

H5 : Motivasi kerja berpengaruh signifikan terhadap kinerja karyawan PT. Tri Wanka Sejahtera

Hasil pengujian pengaruh motivasi terhadap kinerja diperoleh nilai t signifikansi sebesar 0,011. Nilai signifikansi lebih kecil dari 0,05 menunjukan bahwa motivasi berpengaruh signifikan terhadap kinerja. Hal ini berarti Hipotesis 5 diterima.

Hasil Uji Intervening untuk hipotesis 6 dan 7, maka kita harus tentukan dulu nilai dari koefisien deterinannya $\left(\mathrm{R}^{2}\right)$.

Nilai R square dari regresi dapat kita lihat pada tabel berikut:

Tabel 3 Nilai R Square Beban Kerja dan Kompetensi

\begin{tabular}{ccccc}
\hline Model & R & R Square & $\begin{array}{c}\text { Adjusted } \\
\text { R Square }\end{array}$ & Std. Error of the Estimate \\
\hline 1 & $.378^{\mathrm{a}}$ & .143 & .089 & 305.124 \\
\hline
\end{tabular}

a. Predictors: (Constant), BEBAN KERJA, KOMPETENSI

Pada tabel 3 diatas dapat kita lihat bahwa nilai R square nya adalah 0,143, hal ini berarti sebesar $14,3 \%$ motivasi dipengaruhi oleh beban kerja dan kompetensi, sisanya sebesar 85,7\% dipengaruhi oleh variabel lainnya.

Nilai e $1=\sqrt{(1-0,143)}=0,926$ 
Tabel 4 Nilai R Square Motivasi, Beban Kerja, Kompetensi

\begin{tabular}{lcccr}
\hline Model & R & R Square & $\begin{array}{c}\text { Adjusted } \\
\text { R Square }\end{array}$ & Std. Error of the Estimate \\
\hline 1 & $.667^{\mathrm{a}}$ & .445 & .391 & 279.914 \\
\hline a. Predictors: (Constant), MOTIVASI, BEBAN KERJA, KOMPETENSI
\end{tabular}

Pada tabel 4 diatas dapat kita lihat bahwa nilai $\mathrm{R}$ square nya adalah 0,445 , hal ini berarti sebesar 44,5\% kinerja dipengaruhi oleh motivasi, beban kerja, kompetensi, sisanya sebesar 55,5\% dipengaruhi oleh variabel lainnya.

Nilai e2 $=\sqrt{(1-0,445)}=0,745$

Setelah nilai e1 dn e2 kita dapat, maka dapat kita gambarkan analisis jalurnya sebagai berikut:

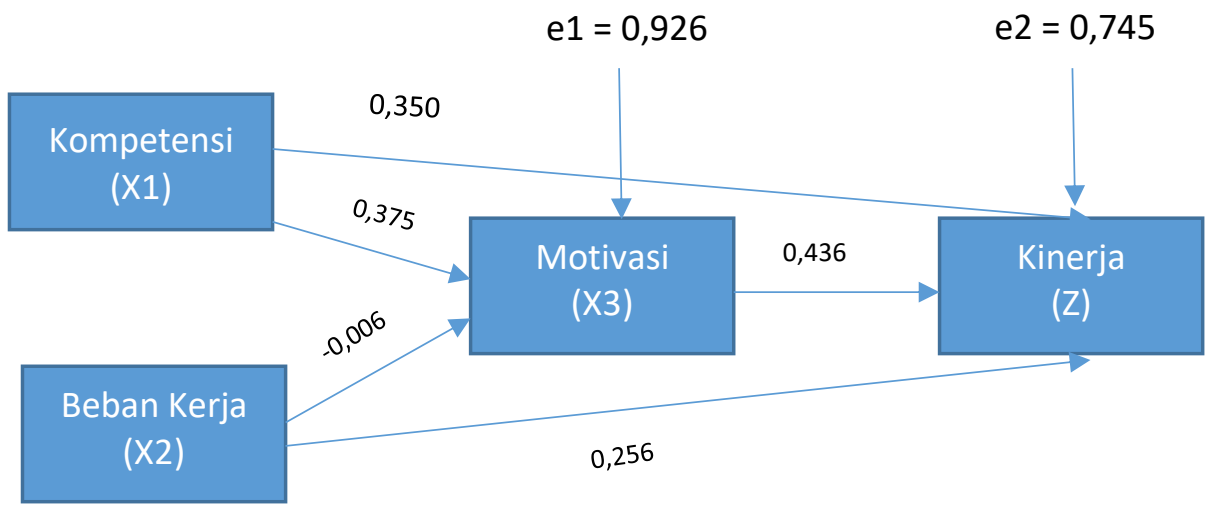

Gambar 1. Kerangka konseptual

\section{Variabel kompetensi terhadap variabel kinerja yang dimediasi oleh motivasi}

H6 : Motivasi memberikan pengaruh yang positif dan signifikan sebagai mediasi antara kompetensi terhadap kinerja karyawan PT. Tri Wanka Sejahtera

Untuk mengetahui bagaiman pengaruh kompetensi terhadap kinerja yang dimediasi oleh motivasi, maka kita terlebih dahulu harus melakukan perhitungan sebagai berikut:

$\mathrm{X} 1 \rightarrow \mathrm{Z}=0,350$

$\mathrm{X} 1$ melalui $\mathrm{Y}$ terhadap $\mathrm{Z}=0,375 \times 0,436=0,164$

Pengaruh total yang diberikn X1 $\rightarrow \mathrm{Z}=0,350+0,164=0,514$

Dari hasil perhitungan diatas, dapapat kita ketahui bahwa pengaruh langsung < pengaruh tidak langsung, dimana $0,350<0,514$. Hal ini berarti bahwa motivasi memberikan pengaruh yang positif dan signifikan sebagai mediasi antara kompetensi terhadap kinerja karyawan PT. Tri Wanka Sejahtera. Sehingga Hipotesis 6 diterima. 


\section{Variabel kompetensi terhadap variabel kinerja yang dimediasi oleh motivasi}

H7 : Motivasi memberikan pengaruh yang positif dan signifikan sebagai mediasi antara beban kerja terhadap kinerja karyawan PT. Tri Wanka Sejahtera

Untuk mengetahui bagaiman pengaruh kompetensi terhadap kinerja yang dimediasi oleh motivasi, maka kita terlebih dahulu harus melakukan perhitungan sebagai berikut:

$\mathrm{X} 2 \rightarrow \mathrm{Z}=0,256$

$\mathrm{X} 2$ melalui $\mathrm{Y}$ terhadap $\mathrm{Z}=-0,006 \times 0,436=-0,00262$

Pengaruh total yang diberikn X2 $\rightarrow \mathrm{Z}=0,256-0,00262=0,253$

Dari hasil perhitungan diatas, dapapat kita ketahui bahwa pengaruh langsung > pengaruh tidak langsung, dimana 0,256>0,253. Hal ini berarti bahwa motivasi tidak memberikan pengaruh yang positif dan signifikan sebagai mediasi antara beban kerja terhadap kinerja karyawan PT. Tri Wanka Sejahtera. Sehingga Hipotesis 7 ditolak.

\section{KESIMPULAN DAN SARAN}

Kesimpulan

Berdasarkan hasil pengujian dan pembahasan hipotesis yang telah dijelaskan sebelumnya, dapat ditarik beberapa kesimpulan sebagai berikut:

1. Kompetensi berpengaruh signifikan terhadap motivasi kerja karyawan PT. Tri Wanka Sejahtera

2. Beban kerja tidak berpengaruh signifikan terhadap motivasi kerja karyawan PT. Tri Wanka Sejahtera

3. Motivasi kerja berpengaruh signifikan terhadap kinerja karyawan PT. Tri Wanka Sejahtera

4. Kompetensi berpengaruh signifikan terhadap kinerja karyawan PT. Tri Wanka Sejahtera

5. Beban kerja berpengaruh signifikan terhadap kinerja karyawan PT. Tri Wanka Sejahtera

6. Kompetensi berpengaruh signifikan terhadap kinerja dengan motivasi kerja sebagai variabel intervening pada karyawan PT. Tri Wanka Sejahtera

7. Beban kerja tidak berpengaruh signifikan terhadap kinerja dengan motivasi kerja sebagai variabel intervening pada karyawan PT. Tri Wanka Sejahtera

Saran

- Karyawan PT. Tri Wanka Sejahtera agar bisa bekerja dengan baik dan mandiri dalam menyelesaikan pekerjaan, dan perusahaan juga harus meningkatkan kompetensi karyawannya agar lebih termotivasi lagi dalam bekerja.

- Bagi peneliti berikutnya agar dapat meneliti dengan variabel-variabel lainnya yang dapat mempengaruhi variabel kinerja. 


\section{DAFTAR RUJUKAN}

Bambang, H. (2004). Sistem Manajemen Basis Data Pemodelan, Perancangan dan Terapannya. Informatika, Bandung.

Bungin, H. Burhan.(2010). Metode Penelitian Kuantitatif, Kencana Prenada Media Group. Jakarta.

Donni, J. Priansa. 2016. Perencanaan Dan Pengembangan SDM. Cetakan Kedua. Alfabeta. Bandung.

Fahriani, M. S. Pengaruh Workload dan Spesialisasi Auditor terhadap Kualitas Audit (Studi Kasus pada Auditor di Kap Big Four). Jurnal Ilmiah Universitas Bakrie, 3(02).

Gunawan, G. Pengaruh Kompetensi Terhadap Kinerja Pegawai Dan Motivasi Sebagai Variabel Intervening Pada Kantor Uptd Pendapatan Wilayah I Palu. Katalogis, 3(1).

Hariyati, M. (2011). Pengaruh Beban Kerja Terhadap Kelelahan Kerja Pada Pekerja Linting Manual Di PT. Djitoe Indonesia Tobacco Surakarta.

Harudi, N., Tamsah, H., \& Gunawan, B. (2016). Pengaruh Motivasi, Disiplin dan Kompetensi terhadap Prestasi Kerja Pegawai Bagian Umum Sekretariat Daerah Kabupaten Soppeng. Jurnal Mirai Management, 1(1), 104-118.

Iskandar, S., \& Sembada, G. G. (2012). Pengaruh Beban Kerja, Motivasi Dan Kepuasan Kerja Terhadap Kinerja Pegawai Bank Bjb Cabang Padalarang. Jurnal Ekonomi, Bisnis \& Entrepreneurship, 6(1), 26-38.

Larasati, S., \& Gilang, A. (2014). Pengaruh Motivasi Kerja terhadap Kinerja Karyawan Wilayah Telkom Jabar Barat Utara (Witel Bekasi). Jurnal Manajemen dan Organisasi, 5(3), 200-213.

Manopo, C. (2011). Competency Based Talent and Performance Management System. Jakarta: Salemba Empat.

Muhammad, S. R., Adolfina, A., \& Lumintang, G. (2016). Pengaruh Lingkungan Kerja, Kompensasi dan Beban Kerja Terhadap Kinerja Karyawan Pada Dinas Pendapatan Daerah Kota Manado. Jurnal EMBA: Jurnal Riset Ekonomi, Manajemen, Bisnis dan Akuntansi, 4(1).

No, P. M. D. N. 12. 2008. Pedoman Analisis Beban Kerja Di Lingkungan Departemen Dalam Negeri dan Pemerintahan Daerah.

Setiawan, L., \& Fitriany, F. (2011). Pengaruh workload dan spesialisasi auditor terhadap kualitas audit dengan kualitas komite audit sebagai variabel pemoderasi. Jurnal akuntansi dan keuangan indonesia, 8(1), 36-53.

Sugiyono. (2017). Metode Penelitian Kuantitatif, Kualitatif, dan R\&D. Bandung: CV. Alfabeta. 
Taroreh, I. M. (2014). Analisa Pengaruh Motivasi Kerja, Pelatihan, Kepemimpinan, Komunikas Dan Kerjasama Tim Terhadap Kinerja Para Suster Dina ST. Yoseph Di Indonesia. Jurnal Riset Bisnis dan Manajemen, 2(4).

Waisnawini, L. G. T. (2014). Pengaruh Lingkungan Kerja dan Stres Kerja Serta Kompensasi terhadap Motivasi Kerja dan Kinerja Karyawan PT. Bank BPD Bali Kantor Cabang Utama Denpasar. Jurnal Bisnis dan Kewirausahaan, 10(1), 68-77.

Wibowo, S. (2010). Manajemen Kinerja-Edisi ketiga, Jakarta: PT. Raja Grafindo Persada.

Yuniarsih, T. Suwatno.(2003). Manajemen Sumber Daya Manusia Teori. Aplikasi dan Isu Penelitian, 129. 